\title{
Remittances, Banking Status and the Usage of Insurance Schemes
}

\author{
Dorothee Crayen \\ Christa Hainz \\ Christiane Ströh de Martínez
}

\author{
CESIFO WORKING PAPER NO. 3117 \\ CATEGORY 12: EMPIRICAL AND THEORETICAL METHODS \\ JULY 2010
}

Presented at CESifo Area Conference on Applied Microeconomics, March 2010

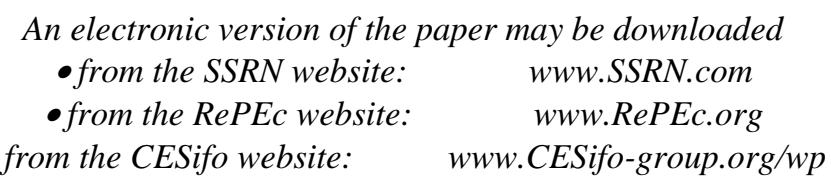




\title{
Remittances, Banking Status and the Usage of Insurance Schemes
}

\begin{abstract}
Empirical evidence that migrants send home more remittances after disasters raises the question of whether remittances can be used to self-insure, substituting for both formal and informal insurance. We investigate this question using a unique data set on the usage patterns of financial services by households in South Africa. We show that the likelihood that a respondent has a formal funeral cover increases with income and banking status. However, it is lower for individuals receiving remittances, which supports the idea that remittances act as (self-) insurance. We also show that purchasing formal funeral cover is influenced by other risk management strategies and that determinants of informal insurance differ from those of formal insurance.
\end{abstract}

JEL-Code: D14, F24, G22, O16.

Keywords: remittances, insurance, risk management strategies.

Dorothee Crayen

University of Tuebingen

Germany - Tuebingen

dorothee.crayen@gmail.com
Christa Hainz

Ifo Institute for Economic Research at the University of Munich

Poschingerstrasse 5

Germany - 81679 Munich

hainz@ifo.de

\footnotetext{
Christiane Ströh de Martínez

Free University of Berlin

Germany-Berlin

christiane.stroeh@gmx.de
}

Draft June 2010 


\section{Introduction}

A good share of rural households borrow, many more save, but all seek to insure against the vagaries of life. In the view of the virtually complete absence of formal insurance markets and social security systems accessible by the poor [...], they use a multitude of measures to reduce the likelihood or impact of risks, either through ex-ante or ex-post measures for smoothing income, consumption or both. (Zeller \& Sharma, 2000, p. 162)

Insurance markets play an important role in fostering economic development. This is also one of the main messages of the World Development Report 2001 (World Bank, 2001). The report highlights the importance of "security.” Thus, what households in developing countries need is access to (some kind of) insurance. In principle, households possess a wide range of measures to cope with risk or insuring schemes. In industrialized countries, formal insurance is widely used; often, it is mandatory or even provided by the government through a social security system. In less developed countries, households rely less on formal insurance and more on semi-formal insurance, including additional risk management strategies to deal with income shocks. The choices households make in selecting ex-ante and ex-post mechanisms to deal with risk are interrelated. One way to deal with ex-post risk is to increase the flow of remittances. Empirical evidence shows that remittances act like insurance. Because different risk management strategies are interrelated, one would like to know whether the fact that a household receives remittances influences its demand for formal insurance?

We investigate this question empirically using a unique dataset for South Africa. The FinScope ${ }^{\mathrm{TM}}$ survey provides information about the usage patterns of all kinds of financial 
services and arrangements. In particular, it contains a comprehensive set of questions on the usage patterns of formal and informal financial services and devices, especially as compared to other surveys (Stone, 2005). For sociocultural reasons, South African people find it extremely important to cover funeral expenses. As a result, a formal funeral cover is the formal insurance cover most widely used by households in South Africa in addition to burial societies, which are informal insurance arrangements. A substantial share of households also receives remittances. ${ }^{1}$ With our data, we address the following questions: 1) Do remittances influence the decision to buy formal funeral cover or to join a burial society; 2) How important is saving, borrowing, and selling assets to deal with shocks; and 3) To what extent does the banking status matter for the kind of funeral cover selected.

In this paper, we argue that remittances provide an income and a self-insurance effect. As remittances increase income, low income individuals that receive remittances will, ceteris paribus, more likely possess formal funeral cover. For them, the higher income relaxes the budget constraint so they can buy funeral cover. For higher income individuals, an increase in income reduces the need to insure if they show absolute decreasing risk aversion; therefore, their use of funeral cover may decrease. However, remittances also provide self-insurance and, thereby, substitute for formal insurance. Because remittances may increase strongly after risk or disaster happens, we believe that the self-insurance effect dominates the income effect if the latter is positive. Thus, we expect that individuals receiving remittances are less likely to possess formal funeral cover. Indeed,

\footnotetext{
${ }^{1}$ About a quarter of respondents in the 2004 FinScope questionnaire indicated that one of their sources of income was money from family members and friends.
} 
the data supports this hypothesis. Once we account for the level of income, the fact that an individual receives remittances decreases the probability of having a formal funeral cover. Moreover, we see that other risk management strategies, such as taking a loan after damage has occurred, influence the usage of formal funeral cover. Interestingly, the determinants of formal funeral cover differ in many ways from those of belonging to a burial society. This might be because the membership in a burial society not only provides informal funeral insurance but also has additional social and cultural aspects. Finally, we provide evidence that the usage of financial services ("bancarization”) matters; in particular, we find that banked households are more likely to have funeral cover, both formal and informal.

The paper is organized as follows: section 2 describes the risk management strategies used by low-income populations; section 3 provides information on the usage patterns of financial services in South Africa; section 4 presents the testable hypotheses about the use of formal insurance schemes; section 5 describes the data, the regression framework and results; and section 6 discusses the results and concludes.

\section{Risk management strategies used by low-income populations}

All households have exposure to some kinds of risk, but with huge differences in the intensity and the frequency of the related shocks, and the ability to deal with them. Lowincome or poor populations often live in riskier or unhealthier environments than the better-off and have fewer resources to prevent or mitigate risks, to cope with the consequences of the related shocks, and to "get back on their feet" (Arun \& Steiner, 2008; Churchill, 2006; Cohen \& Sebastad, 2006). Vulnerability to risks, such as illness, 
disability, crop loss, lack of income generation opportunities, or natural disasters, hence relates closely to material poverty. Regarding exposure to risks, the trajectory out of poverty is a zigzagging route, where advances reflect periods of income growth and asset building, and declines reflect the impact of shocks, emergencies, and economic stress (Cohen \& Sebastad, 2006). Accordingly, the path of many people into poverty can also be seen as linked to shocks and emergencies when low-income people do not have (access to) adequate risk-management mechanisms. Social security or safety nets and the enhanced ability of poor and low-income people to mitigate risks and cope with adverse shocks are consequently fundamental for sustained poverty reduction (World Bank, 2001).

Considering the unexpected and expected risks mentioned by low-income households, one can differentiate the idiosyncratic and covariant risks. The major concern for many respondents and, presumably, the greatest burden on their household budgets is of a personal nature, especially health-, disability- and death-related risks (e.g., Cohen \& Sebastad, 2006).

Amid the context of limited coverage through social safety nets and access to (or usage of) formal insurance products in most developing countries, low-income populations employ a large variety of strategies for dealing with risk; thus, risk mitigation can take place at two different stages. The first stage refers to ex-ante arrangements to avoid exposure to risk, which aims at protecting income shortfalls before they occur. Measures for lowering ex-ante risk consist mainly of conservative production decisions, such as 
planting safe, low-yielding seed varieties or mixed cropping, and in diversifying the household's economic activities. Such arrangements, however, often entail losses in profitability of the respective economic activities (Morduch, 1995; Ruthven \& Kumar, 2002). Anticipating measures to reduce exposure to risk show low-income populations' awareness of relevant risks and their limited possibilities for dealing with the shock once it occurs.

The second stage refers to both ex-ante and ex-post mechanisms for dealing with damage and related negative income shocks that occur within households. Ex-ante arrangements for dealing with potential damage include reducing consumption, creating savings, and insuring through both formal and informal insurance schemes. Ex-post mechanisms comprise borrowing, receiving remittances, reducing consumption, or increasing working time (Morduch, 1995). The latter coping mechanisms of reducing consumption may affect the family's nutrition or education level (e.g., children are taken out of school after adverse shocks) (Jacoby \& Skoufias, 1992); whereas, the extension of working hours may affect the health or social situation of the family. Financial arrangements, hence, constitute important options for dealing with damage and related shocks.

In-depth studies on financial management of low-income and poor households like Financial Diaries show that different formal, semi-formal, and informal arrangements and services combine into a large number of small transactions to gather the lump sums they need from their small and mostly unstable income streams. The financial instruments for different money management needs relate to life-cycle needs, emergencies, and seasonal 
or economic opportunities (Rutherford, 2003; Ruthven \& Kumar, 2002; Collins, 2004). Hence, poor households employ distinct informal and formal financial arrangements for dealing with shocks, including borrowing, lending, saving, and taking part in insurance societies, such as burial societies or buying (micro)insurance policies (Rutherford, 2001).

Although combining mechanisms is possible, ex-ante and ex-post mechanisms of dealing with the damage are, of course, substitutes. The literature argues that remittances act like insurance with evidence on both the macro and the micro level. On the macro level, Mohapatra, Joseph and Ratha (2009) use cross-sectional data for a large number of countries and reveal that, in countries with a significant proportion of migrants, the flow of remittances significantly increases, both statistically and economically, after a natural disaster. ${ }^{2}$ Yang (2007) focuses on the impact of hurricanes in a sample of developing countries. In the poorer half of the sample, remittances increase significantly after a hurricane.

Several researchers study the effect of income shocks on the level of remittances by using household data. Gubert (2002) provides evidence for a region in Mali where crop failure engendered an increase in national and international remittances. Other studies use natural disasters as their identification strategy. Yang and Choi (2007) analyze household panel data for the Philippines and measure changes in local rainfall as an exogenous shock. They show that remittance inflows from other countries replace roughly 60

2 They also show that remittances influence decisions in the first stage. Households with remittances are more likely to possess a concrete house and have better access to means of communication (Mohapatra, Joseph \& Ratha, 2009). 
percent of exogenous declines in income. However, they find no effect on income decline on remittance receipts for households without overseas migrants. Using a panel of the LSMS from Jamaica, Clarke and Wallsten (2003) reveal that remittances increase by 25 percent for every dollar of damage inflicted by hurricane Gilbert at the household level. Given this evidence, the question arises whether remittances influence the demand for insurance and, ultimately, its use.

Many other financial services besides insurance can fulfill financial arrangements for risk mitigation. This wider notion of financial devices used for "insuring” refers to different risk-prevention and risk-management strategies, including reciprocity- and relationshipbased lending and borrowing strategies, and individual savings. Therefore, a comprehensive analysis needs to consider different kinds of risk management strategies, such as savings, borrowing, and funeral cover schemes. .

\section{Usage patterns of financial services in South Africa}

The most recent Human Development Report 2007/2008 noted that inequality remains one of the central challenges for human development in South Africa. Although the country ranks $56^{\text {th }}$ in GDP per capita, it offers a Human Development Index (HDI) ranking of $125^{\text {th }}$ of 179 countries. Since 1975, following composition of the first HDI, the measures of human well-being in South Africa has improved slightly from 0.653 to 0.741 in 1994. Since then, South Africa’s Human Development Index has regressed to 0.670 in 2006, due mainly to low life expectancy at birth, low literacy, and low school enrollment (UNDP, 2008). However, it also relates to the HIV/AIDS pandemic, to the sharp rise in unemployment, to informal employment, and to income inequality. Income inequality 
remains high between racial and occupational groups, among different educational levels, between regions, and between urban and rural areas. The differential for occupation surpasses the ones for education and race (Leite et al., 2006). Socioeconomic inequality in South Africa is strong despite a social pension system with grants for children, disabled, and elderly people, which underwent reform and opened to all South African citizens post-Apartheid. Generally, the main objective of the social welfare system is to lift needy people out of poverty (Triegaardt, 2005).

As in many other developing countries, there is not only a significant percentage of international but also national migration. From 1994 until 2007, before Zimbabweans have begun flowing into South Africa in very large numbers, South Africa has an estimated negative net migration rate. The majority of emigrants are middle-aged Caucasians moving to the UK, Australia, and the USA (Cronje, 2006). However, there is an internal labor migration increase post-Apartheid. As such, 33 percent of rural African households contain migrant household members in 1993; by 1999, this has risen to 36 percent among those seeking employment elsewhere (Posel, 2003). Consequently, an increasing proportion of the population receives remittances regularly. Based on census and survey data, Posel (2003) concludes that approximately 79 percent of all rural African households with migrant workers have received remittance income in 1993; by 1999, this has increased to 85 percent. At the same time, nearly half of the 7 percent of the population that migrate within South Africa are away from their family home for more than five years but visit their families regularly (Truen et al., 2005). 
Access to and usage of financial services also differs strongly in the heterogeneous society. While roughly half of the South African population had bank accounts in 2006, the white and the wealthiest of the population retain the highest level of bancarization at over $90 \%$. However, increasing shares of the black and coloured population have bank accounts, reaching $45 \%$ and $53 \%$ in 2006, respectively. The difference between urban and rural populations remains, although urban and rural populations have become increasingly familiar with banks, except for tribal populations, which remain at $30 \%$. Considering the differences by Living Standards Measure (LSM) ${ }^{3}$, the lowest classes remain at around $20 \%$ banked; whereas, the probability of having a bank account increases strongly in the medium and lower classes from 32-48\% to 35-61\% (FinScope Data, 2004-2006). The most important link to a bank, corresponding to $48 \%$ of the population, consists of ATM cards, which may be partly due to the payment system of governmental social grants and pensions through ATMs (Overbye, 2005).

The second most popular financial service - even more preferred than savings/transaction accounts - is funeral insurance with $39 \%$ of the population either holding a formal funeral cover or belonging to a burial society. ${ }^{4}$ Hence, as indicated by the nationally representative FinScope data sample, a funeral cover is the only widely used insurance or risk-mitigating financial service. The most popular kind of insurance is burial societies, held by $23 \%$ of the population. Membership in burial societies generally covers up to six people, and is most common among black and coloured populations. Formal funeral

\footnotetext{
${ }^{3}$ The LSM is a categorization ranging from 1 to 10 and providing a rough proxy for wealth; the lower numbers comprise the poorest part of the population.

${ }^{4}$ Loans and other insurance are held by around $10 \%$ or less of the population, and retail or store card are used by $20 \%$ of the population (FinScope Data, 2004-2006).
} 
cover directly from an undertaker is another popular form of insurance used mostly within the coloured community. Banks or insurance companies offer formal funeral cover and are most frequently purchased by white populations. The usage pattern of funeral cover is, thus, quite different from bancarization trends and much more equally distributed by race. The coverage of black, white, and coloured is between 36-59\%; only the Asian population shows low coverage at $25 \%$. The fact that burial societies generally cover large families adds to a high equality in funeral coverage.

Funeral cover offered in South Africa by insurance companies has periodically renewable term coverage. This means that the insurer can cancel the policy at any time. ${ }^{5}$ In order to obtain a funeral cover, applicants usually need to answer questions concerning their health but a health check is not required (Cameron, 2003) ${ }^{6}$ There are about 30 insurance companies offering funeral cover with most offering minimum coverage of R 5,000. In 1998, only two companies offer policies with lower coverage (Roth, 2000). For example, the monthly premium for a cover of R 3,000 for a single person between the ages of 14 and 59 is R 30 (http://www.insurance.za.org/funeral-insurance.htm). There is also a maximum cover, which limits the possibility of using a funeral cover as life insurance through which the bereaved can be provisioned (Roth, 2000).

\footnotetext{
${ }^{5}$ In contrast, normal life insurance policies are sold for periods of at least five years in order to protect costumers from a sudden loss of their coverage (Cameron, 2003).

${ }^{6}$ Even for person with HIV/AIDS, there are ways to obtain a funeral policy (Cameron, 2003). The fact that there is a market for funeral cover shows that the insurance companies found a way to deal with the resulting adverse selection problem. We, thus, are of the opinion that the adverse selection problem does not influence the effect of income and remittances on the insurance decision.
} 
The Financial Diary research in South Africa suggests that more than three quarters of the respondents hold at least one, and more than half has at least two types of funeral coverage. ${ }^{7}$ Because of the frequency and the premature deaths of the respondents within their household or within the larger family, due in part to HIV/AIDS, and because of the high funeral costs, generally up to seven months of income, households use a variety of financial instruments to deal with these expenses and spend approximately $3 \%$ of their gross monthly income on funeral arrangements (Collins, \& Morduch, in press). Even though households spend a significant proportion of their income on funeral insurance schemes, payouts from the burial society and the formal insurance coverage generally requires subsidization by remittances or in-kind contributions from relatives, savings, or a loan to cover the expenditures related to a funeral. In addition to fees for the undertaker, the cost of food for mourners is an important expenditure especially in rural areas where the "umkhululo" ("the feast to take off the mourning clothes") occurs one month after the funeral (Financial Diaries, n.d.a). Besides the financial contribution, the emotional and practical support of burial society members plays an important role, especially with preparing and serving the feast during the burial, providing utensils for cooking, etc. (Financial Diaries n.d.b). Hence, there needs to be a complex mix of formal and informal instruments for insuring funeral costs, going beyond the different funeral schemes.

\section{Links between different financial arrangements and hypotheses}

We investigate the relationship between different risk management strategies. In particular, we study the ways in which receiving remittances influences the demand for

\footnotetext{
${ }^{7}$ The Financial Diary gives in-depth insights into the financial lives of the respondents without claiming to be representative.
} 
insurance. We look at this question from the ex-ante perspective, which is the point in time when an individual decides to buy insurance coverage before damage occurs. Using our data, we determine whether an individual has funeral cover; however, we do not consider the coverage rate usually derived from a theoretical model. Thus, we will explain the individual's decision to purchase optimal coverage rate in a theoretical model, and argue that this influences whether an individual has an insurance policy.

We use the model and notation similar to the one by Rees and Wambach (2008) but add expected remittances. In the model, the individual has a wealth of $W{ }^{8}$ He may suffer a loss, $L$, in the bad state of the world, which occurs with probability, $p$. In the context of our research, the bad state occurs when there is a death and funeral costs, $L$, are due. Individuals can buy cover $C$, paying a fair premium of $p C$. We assume the insurance premium is fair in order to keep the analysis as simple as possible. In addition to the standard model, individuals expect remittances, noted as $R^{g}$ in the good state of the world, and $R^{b}$ in the bad state with $R^{b}>R^{g}$. The empirical evidence that a migrant increases the amount of remittances after the individual faces a loss justifies this assumption. Thus, the expected utility, $\bar{u}$, with $u^{\prime}>0$ and $u^{\prime \prime} \leq \geq 0$, depending on the degree of risk aversion, is:

$$
\bar{u}=(1-p) u\left(W+R^{g}-p C\right)+p u\left(W+R^{b}-L-p C+C\right)
$$

\footnotetext{
${ }^{8}$ For instance, wealth can be accumulated by saving. We did not study the intertemporal choice of a household explicitly, but focused on the (insurance) decision of how best to shift income between different states of being.
} 
The individual maximizes the expected utility through the choice of $C$. When solving the optimization problem, the individual has to respect that there is:

- a lower threshold, $\underline{C}$, below which no insurance cover is offered, which we call feasibility constraint

$$
C \geq \underline{C}
$$

- and the budget constraint

$$
W+R^{g} \geq p C
$$

Given that we assume a fair insurance premium, the result of the optimization is that the marginal utilities between the good and bad states are the same. This implies that the payoffs in both states must be identical, i.e.,

$$
\begin{aligned}
& W+R^{g}-p C^{*}=W+R^{b}-L-p C^{*}+C^{*} \text { or } \\
& R^{b}-R^{g}=L-C^{*}
\end{aligned}
$$

Since $R^{b}-R^{g}>0$, it is optimal to buy only partial coverage. In the standard model without remittances, the optimal solution is to have full coverage. In addition, the individual must respect feasibility and budget constraints. This implies that if $C^{*}<\underline{C}$, the individual must decide whether to buy more $(C=\underline{C})$ or less coverage $(C=0)$ than the optimal. The existence of the feasibility constraint renders the budget constraint more demanding.

Reviewing comparative statistics offers insight. If the individual's wealth, $W$, increases, the effect on insurance coverage depends on the degree of absolute risk aversion. Usually, the insurance literature posits that the degree of absolute risk aversion decreases with income, i.e., $u^{\prime \prime}<0$, implying that the demand for insurance decreases with income. 
In our study, income consists of $W$ and remittances. For analytical purposes, we can split $R^{b}=R^{g}+I$. Thus, an individual with remittances in the amount of $R^{g}$ has a higher income and is thus less likely to have funeral cover. However, for individuals with remittances, budget constraints (given that the feasibility constraint exists) will be more likely fulfilled, which means he will be more likely to possess funeral cover. Thus, we basically have two countervailing effects, which remittances produce on the demand for insurance due to higher income. However, the direction of the effects differs for individuals depending on their income level. For low income individuals, remittances increase income, thus budget constraints are no longer binding and allow them to buy insurance cover. For higher income individuals, in which budget constraints are not binding even without remittances, remittances decrease the demand for insurance. Therefore, the probability that an individual has a funeral policy decreases. Accordingly, we derive the following testable hypotheses:

Hypothesis 1. Higher income increases (decreases) the probability that an individual possesses formal funeral cover if the income level is low (high).

The difference between wealth and remittances is that the amount of remittances varies between good and bad states. The empirical evidence provided before shows that remittances increase in the case of an adverse event, i.e., in the bad state of the world. Thus, for an individual with remittances, optimal cover is lower than for an individual without remittances. Remittances provide what Schlesinger (2000) calls self-insurance. Therefore, we expect that individuals with remittances are less likely to possess funeral cover. When we control for income, we can formulate: 
Hypothesis 2: An individual is less likely to possess formal funeral cover if he receives remittances.

Furthermore, different distribution channels sell formal funeral coverage. Banks give financial advice and sell insurance. If an individual regularly interacts with the bank, the bank can use this contact to sell insurance products. Our hypothesis is:

Hypothesis 3: An individual is more likely to possess formal funeral cover if he regularly interacts with a bank.

One option individuals can choose besides buying formal funeral cover or having no insurance cover is informal insurance obtained by becoming a member of a burial society. In addition to providing insurance, being a member of a burial society has bearings on the individual's network and community relations and implies various nonmonetary benefits, such as practical assistance with funeral arrangements. Thus, joining a burial society is a much more complex decision than buying formal funeral cover. Accordingly, we expect that, for membership in a burial society, the effects captured in hypotheses 1-3 for formal funeral cover will show significant differences.

\section{Empirical Analysis}

We use a unique data set, the surveys of FinScopeTM (www.finscope.co.za), on the access to and usage of both formal financial services as well as semi-formal and informal financial products. This represents a FinMark Trust initiative and consists of a series of comprehensive national household surveys on the people's perceptions, needs, and usage patterns related to all kind of financial services and arrangements. FinMark Trust did the 
first survey in 2003 in South Africa, which was repeated, adapted, and applied to other African countries (Porteous, 2007). We use the 2004 South African data because it is the first household survey to include a wide set of questions on financial behavior. In 2004, the data was benchmarked to Census 2001 figures, i.e., the population reflected the total according to the 2001 census. The sample was drawn from the national household samples. Because of the limited comparability of the surveys, both across countries and across years, we focus on the 2004 survey in South Africa, which includes all the central variables relevant for our analysis.

\section{The regression framework}

Our hypotheses revolve around individual choices for formal funeral cover. ${ }^{9}$ We define our dependent variable accordingly. The binary dependent variable 'formal funeral cover' takes the value 1 if the respondent holds either a funeral policy or takes part in a formal funeral scheme (0 if not). The probability of having formal funeral cover is modeled as a maximum-likelihood logit function of both individual and household characteristics added to remittances, household income per capita, banking status, risk coping information, and risk perception. ${ }^{10}$ All models are estimated using robust standard errors and sampling weights provided by FinMark Trust.

\footnotetext{
${ }^{9}$ We provide regression results for membership in a burial society at the end to highlight the differences.

${ }^{10}$ For basic diagnostics on model specification, multicollinearity, and influential data, see the appendix.
} 


\section{Variables}

The binary dependent variable indicates whether the individual holds a formal funeral cover, which might be a funeral scheme or a funeral policy (yes=1, no=0). As shown in Table 1 of the descriptive statistics, about one fifth of the respondents hold some type of formal funeral cover.

Table 1: Descriptive Statistics

\begin{tabular}{lccc} 
& Mean & Minimum & Maximum \\
\hline Holding a formal funeral cover & 0.19 & 0 & 1 \\
Belonging to a burial society & 0.23 & 0 & 1 \\
\hline Monthly household income per capita in ZAR & 1107.95 & 0 & 300,000 \\
& & & \\
Remittances & & & \\
\hline Remittances & 0.26 & 0 & 1 \\
Interaction remittances and hh income p.c. & 167.26 & 0 & 22,500
\end{tabular}

Banking information:

\begin{tabular}{llll}
\hline Being banked & 0.60 & 0 & 1 \\
Institutionalized money transfer & 0.29 & 0 & 1 \\
Physical access to formal fin. Institutions & 3.48 & 1 & 8
\end{tabular}

Risk perception:

A household-specific risk is likely to happen

$\begin{array}{lll}0.61 & 0 & 1 \\ 0.19 & 0 & 1 \\ 0.14 & 0 & 1\end{array}$

$\mathrm{T}$ he main wage earner is likely to die

Coping strategies:

\begin{tabular}{llll}
\hline Sell Assets & 0.03 & 0 & 1 \\
Take a formal loan & 0.09 & 0 & 1 \\
Take an informal loan & 0.34 & 0 & 1 \\
Cash in insurance policies & 0.03 & 0 & 1 \\
Apply for a govt. grant & 0.07 & 0 & 1 \\
Withdraw Savings & 0.09 & 0 & 1 \\
& & & \\
Other Controls & & & 1 \\
"Help available" & 0.72 & 0 & 1 \\
"Feel well" & 0.50 & 0 & 1 \\
Head of household & 0.54 & 0 &
\end{tabular}

Data source: FinScope South Africa 2004; see main text for details. 
Although formal funeral cover is most common in formal urban areas, it permeates all sectors of society, and exists among 12-13 percent of the people living in tribal lands, rural, formal, and urban informal areas (FinScope Data, 2004; see also Napier et al., 2007). As can be seen from the descriptive statistics, membership in burial societies is generally slightly higher.

Using the information provided by the FinScope questionnaire, we construct a variable capturing monthly household income per capita (given in South African Rand) to test Hypothesis $1 .{ }^{11}$ To account for a changing pattern of income effects along the entire set of income ranges, we generate seven income classes (thresholds at the 10th, 25th, 50th, 75th and 90th percentiles, plus one category for "no income"). We include one dummy for each of the classes in the regression analysis.

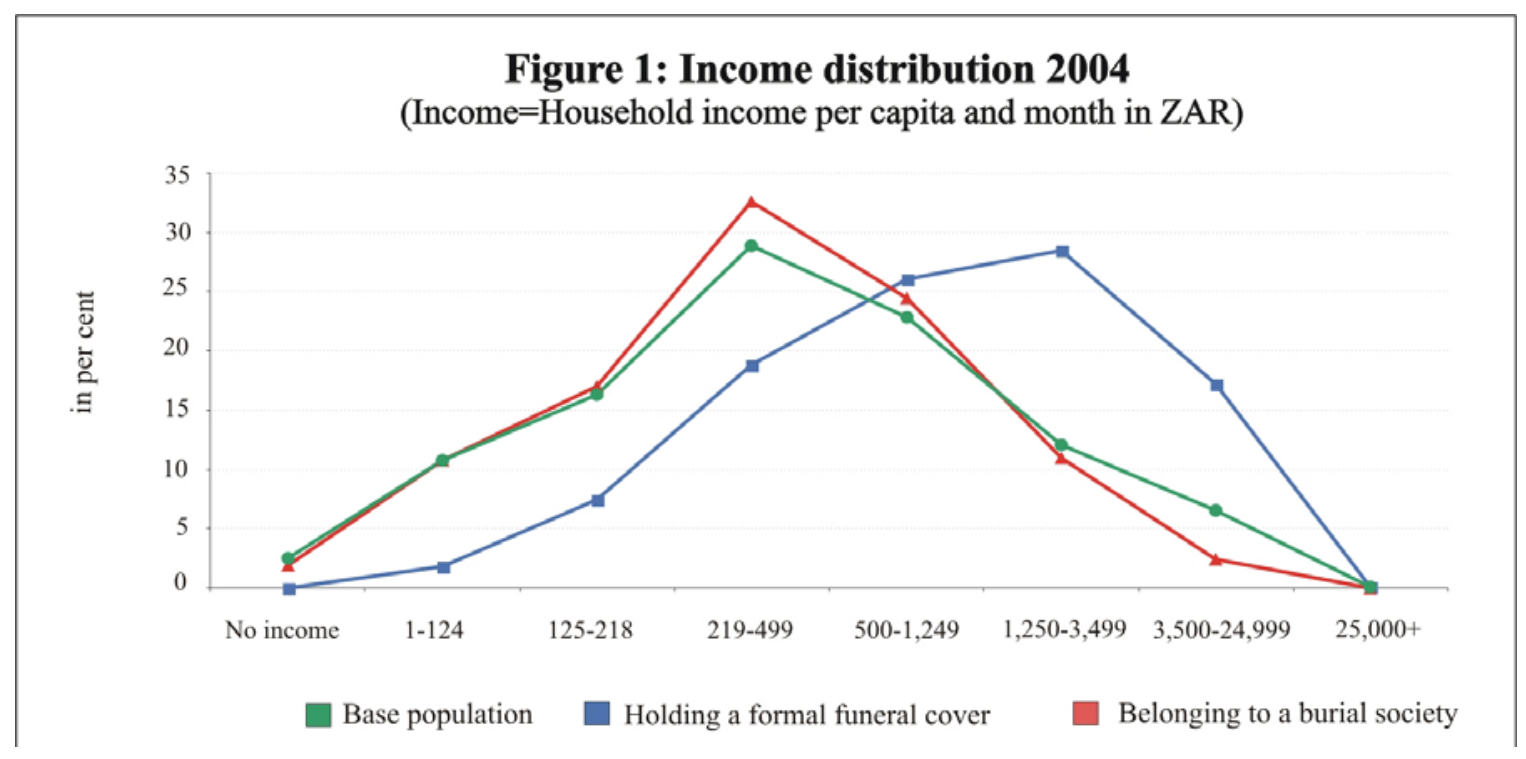

\footnotetext{
${ }^{11}$ We exclude all respondents unwilling or unable to provide information on their monthly household income. We approximate monthly household income by the mean of the respective income group. For the open income class, "ZAR 200.000 and higher," we define an approximate household income of ZAR 300.000. Next, we divide monthly household income by the total number of people in the household.
} 
Figure 1 shows the distribution of monthly household income per capita for both the entire sample and the sub-group of respondents holding formal funeral cover. It appears that formal funeral cover is associated with higher incomes. A disproportionately high share of respondents holding formal funeral cover is from higher income classes, implying an income above ZAR 1.250 per month and per household member. In contrast, the income distribution for burial society members is similar to the income distribution for the entire sample, with the bulk of observations receiving a per capita income between ZAR 125 and ZAR 1.249.

For testing Hypothesis 2, we identify respondents who receive remittances. Our explanatory remittance variable takes the value 1 for about a quarter of the respondents stating their individual source of income is 'through family members or friends'. We control for the level of monthly household income per capita. ${ }^{12}$ In case the self-insurance effect dominates the (possibly) positive income effect, our analysis will yield a negative coefficient of the remittance variable. We also look at the combined effects of income and remittances. After all, remittances may have a greater effect on some income categories than on others. We thus include interaction effects using additional variables interacting the various income categories with the remittances dummy.

\footnotetext{
${ }^{12}$ If the part of income made up of remittances is not perfectly captured by the household income variable, remittances will have a positive effect on the probability of buying formal funeral cover.
} 


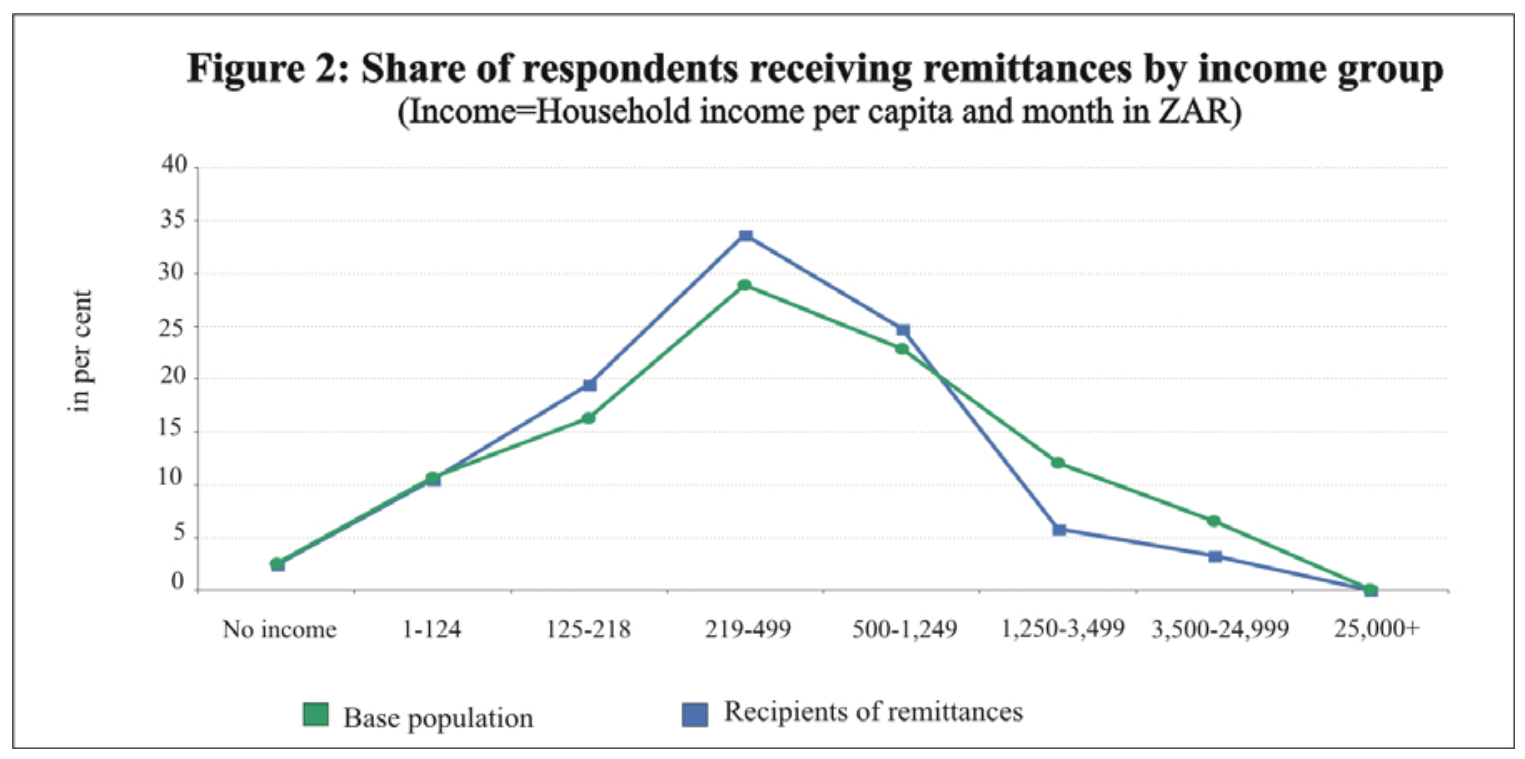

As can be seen in Figure 2, the shape of the income distribution for recipients of remittances broadly follows the form of the overall income distribution. There is a higher concentration on middle income groups up to a monthly per capita income of ZAR1.249, and a thinner right tail of distribution. This indicates that middle income families depend on remittances more often than do others.

Besides remittances, the household can use different risk coping mechanisms to deal with income shocks. From the questionnaire, we know the preferred risk coping strategy by household, and can regard these mechanisms as substitutes for formal insurance cover. We define several binary variables reflecting the individual's risk management strategies based on the question 'Manner in how to deal with occurrence'. Controlling for other factors, such as income and remittances, we are thus able to understand the impact of the respondent's attitude towards different ex-post risk management strategies on his or her preference for formal or informal insurance products. One-third of the respondents note they will take an informal loan if they experience a negative income shock. Other 
relevant risk coping strategies include selling assets, taking formal loans, cashing in insurance policies, applying for government grants, and withdrawing savings. As a complementary factor to an individual's risk management strategies, we include the explanatory variable "help available,” indicating whether the respondent confirms the statement "I have friends and family to turn to whenever I need them” (0-no, 1-yes).

We also include psychological factors, such as risk perception. We define three variables indicating whether the respondent perceive general threats, such as droughts and floods ('general risk'), or household specific risks, such as theft or fire ('household risk'), as likely to happen. Because we assess the determinant of funeral cover purchases, we specifically account for respondents who see financial danger if the family's main wage earner dies ('death risk'). Given their reduced capability to compensate for negative income shocks, we expect people who feel sick to take more precautionary measures than do those feeling healthy and strong. For this reason, we include information on the respondent's individual well-being, captured by the statement "I feel well and in good health” (0-no, 1-yes).

In Hypothesis 3, we emphasize insurance distribution channels and the individual's interaction with banks. There are several approaches, and we include different measures in our regression analysis. A first approximation of people's interaction with banking facilities is their banking status. We regard individuals as banked, if they are currently banked or have previously been banked. We also examine whether individuals with money usually transferred to a bank have a systematically higher probability of buying 
formal funeral cover than are others since they are regularly exposed to the marketing activities of bank employees. The binary variable indicator "Institutionalized money transfer" is based on the answer to the question "How do you usually receive money?”. It takes the value 1 if the respondent uses institutionalized services when receiving money. ${ }^{13}$ Since multiple answers are permitted, channels of money transfer are not mutually exclusive. We probe the determinants of buying formal funeral cover more deeply using the more differentiated "Index of physical access to formal financial institutions," which summarizes the time respondents spend traveling to the bank and related statements. Based on their access to formal financial institutions, respondents group into eight tiers with higher scores indicating better access to formal financial institutions. We expect respondents with easier access to banking facilities to be more prone to interact with banks. Following our line of argument, these individuals are more likely to purchase formal funeral cover.

We limit our analysis to individuals of legal age, i.e., age 18 and older, which is a requirement for buying a formal insurance policy. We account for the level of education using seven categories ranging from 1 'no formal education' to 8 'masters degree or higher'. As additional control variables, we include a set of personal and household demographics, such as gender, age, race, type of settlement (urban vs. rural; formal vs. informal), and province in our regression model. ${ }^{14}$

\footnotetext{
${ }^{13}$ The variable takes the value 1 if the respondent receives money through a bank, by check, by electronic bank transfer, by collecting money from the post office, by using the services such as Western Union, or by telegraphic transfer, and 0 otherwise.

${ }^{14}$ We do not report the coefficients of these variables for clarity in the main regression table. See the appendix for marginal effects of all control variables.
} 


\section{Results}

Table 2 reports the estimated marginal effects of each explanatory variable evaluated at the mean of all variables. For binary variables, $d y / d x$ stands for a discrete change of the dummy variable from 0 to 1 . Our first regression explains the probability of having acquired a formal funeral cover by per capita income and remittances. Successively, we add information on the degree of interaction with banks and comparable institutions, as well as variables capturing the interaction effect between remittances and different levels of income. In the third regression, we account for the respondent's risk assessment, his or her risk coping strategies, and additional control variables, such as education and ethnic group. Our last regression analyzes the probability of being member of a burial society in the same way as counting formal funeral cover.

Our results show that positive household income significantly increases the demand for formal funeral cover as in Hypothesis 1. For the groups between the 10th and the 90th percentile of the income distribution, the positive effect is strong and consistent even when we include additional explanatory variables in our regression on formal funeral cover. In the lowest income group (monthly income up to ZAR 124 per capita), additional income does not increase the propensity to buy formal funeral cover once we account for familiarity with the banking system. This suggests that for low income individuals, the budget constraint, influenced by the feasibility constraint, is binding and they can not afford to buy the lowest available coverage (Hypothesis 1). For higher income individuals, the probability that they will buy formal funeral cover is higher than 
in the reference category. Thus, they are more likely able to afford funeral cover. Interestingly, the income effect becomes larger as income increases. Finally, individuals in the highest income class have the same low probability of possessing funeral cover as do the individuals without income, which is the reference category. This is in line with our prediction that an income increase for individuals above a certain threshold decreases the use of formal funeral cover, which is based on the assumption of decreasing absolute risk aversion. From the magnitude of the marginal effects, we see that income is the most important of all explanatory variables.

\section{Table 2: Funeral cover coverage: marginal effects from logit}

\begin{tabular}{|c|c|c|c|c|}
\hline Dependent variable: holding/belonging to a... & \multicolumn{3}{|c|}{ Formal funeral cover } & Burial society \\
\hline Independent variable & $\mathrm{dy} / \mathrm{dx}$ & $\mathrm{dy} / \mathrm{dx}$ & $\mathrm{dy} / \mathrm{dx}$ & $\mathrm{dy} / \mathrm{dx}$ \\
\hline Monthly household income per capita in ZAR: & $(1)$ & $(2)$ & $(3)$ & $(4)$ \\
\hline No income & & reference & & reference \\
\hline ]0;124[ & $\begin{array}{l}0.48^{*} \\
(0.25)\end{array}$ & $\begin{array}{c}0.33 \\
(0.25)\end{array}$ & $\begin{array}{c}0.17 \\
(0.20)\end{array}$ & $\begin{array}{c}0.09 \\
(0.09)\end{array}$ \\
\hline$[125 ; 219[$ & $\begin{array}{c}0.68 * * * \\
(0.17)\end{array}$ & $\begin{array}{c}0.56^{* * * *} \\
(0.22)\end{array}$ & $\begin{array}{l}0.38^{*} \\
(0.23)\end{array}$ & $\begin{array}{c}0.10 \\
(0.08)\end{array}$ \\
\hline$[219 ; 500[$ & $\begin{array}{c}0.68 * * * \\
(0.16)\end{array}$ & $\begin{array}{c}0.50 * * * \\
(0.19)\end{array}$ & $\begin{array}{l}0.29 * \\
(0.18)\end{array}$ & $\begin{array}{c}0.10 \\
(0.07)\end{array}$ \\
\hline$[500 ; 1,250[$ & $\begin{array}{c}0.80 * * * \\
(0.11)\end{array}$ & $\begin{array}{c}0.60 * * * \\
(0.19)\end{array}$ & $\begin{array}{c}0.42^{* *} \\
(0.21)\end{array}$ & $\begin{array}{c}0.06 \\
(0.07)\end{array}$ \\
\hline$[1,250 ; 3,500[$ & $\begin{array}{c}0.88 * * * \\
(0.05)\end{array}$ & $\begin{array}{c}0.75^{* * *} \\
(0.14)\end{array}$ & $\begin{array}{c}0.59 * * * \\
(0.22)\end{array}$ & $\begin{array}{c}0.09 \\
(0.09)\end{array}$ \\
\hline$[3,500 ; 25,000[$ & $\begin{array}{c}0.88 * * * \\
(0.03)\end{array}$ & $\begin{array}{c}0.77 * * * \\
(0.12)\end{array}$ & $\begin{array}{c}0.59 * * \\
(0.24)\end{array}$ & $\begin{array}{c}0.03 \\
(0.10)\end{array}$ \\
\hline More than 25.000 ZAR p.c. and month & $\begin{array}{c}0.81^{* * *} \\
(0.09)\end{array}$ & $\begin{array}{c}0.50 \\
(0.38)\end{array}$ & $\begin{array}{c}0.21 \\
(0.37)\end{array}$ & dropped \\
\hline Remittances & & & & \\
\hline Remittances & $\begin{array}{c}-0.12 * * * \\
(0.02)\end{array}$ & $\begin{array}{c}-0.08 * * * \\
(0.02)\end{array}$ & $\begin{array}{l}-0.07^{*} \\
(0.04)\end{array}$ & $\begin{array}{c}0.02 \\
(0.08)\end{array}$ \\
\hline Interaction remittances and household income & & & & \\
\hline Remittances*]0;124[ & & & $\begin{array}{c}0.00 \\
(0.00)\end{array}$ & $\begin{array}{c}0.00 \\
(0.00)\end{array}$ \\
\hline Remittances* [125;219[ & & & $\begin{array}{c}0.00 \\
(0.00)\end{array}$ & $\begin{array}{c}0.00 \\
(0.00)\end{array}$ \\
\hline Remittances* [219;500[ & & & $\begin{array}{l}-0.00 \\
(0.00)\end{array}$ & $\begin{array}{c}0.00 \\
(0.00)\end{array}$ \\
\hline Remittances* [500;1,250[ & & & $\begin{array}{c}0.00 \\
(0.00)\end{array}$ & $\begin{array}{c}0.00 \\
(0.00)\end{array}$ \\
\hline Remittances* [1,250;3,500[ & & & $\begin{array}{c}0.00 \\
(0.00)\end{array}$ & $\begin{array}{l}-0.00 \\
(0.00)\end{array}$ \\
\hline Remittances* [3,500;25,000[ & & & $\begin{array}{c}0.00 \\
(0.00)\end{array}$ & $\begin{array}{l}-0.00 \\
(0.00)\end{array}$ \\
\hline Banking information: & & & & \\
\hline
\end{tabular}




\begin{tabular}{|c|c|c|c|c|}
\hline Being banked & & $\begin{array}{c}0.07 * * * \\
(0.02)\end{array}$ & $\begin{array}{c}0.04^{* *} \\
(0.02)\end{array}$ & $\begin{array}{c}0.07 * * * \\
(0.03)\end{array}$ \\
\hline Institutionalized money transfer & & $\begin{array}{c}0.06^{* * *} \\
(0.02)\end{array}$ & $\begin{array}{c}0.05^{* * *} \\
(0.02)\end{array}$ & $\begin{array}{c}0.02 \\
(0.03)\end{array}$ \\
\hline $\begin{array}{l}\text { Physical access to formal financial institutions } \\
\text { Risk perception: }\end{array}$ & & $\begin{array}{c}0.02 * * * \\
(0.00)\end{array}$ & $\begin{array}{c}0.02 * * * \\
(0.00)\end{array}$ & $\begin{array}{c}0.00 \\
(0.01)\end{array}$ \\
\hline A household-specific risk is likely to happen & & & $\begin{array}{c}0.02 \\
(0.02)\end{array}$ & $\begin{array}{c}0.00 \\
(0.03)\end{array}$ \\
\hline A general risk is likely to happen & & & $\begin{array}{c}0.02 \\
(0.02)\end{array}$ & $\begin{array}{l}-0.02 \\
(0.03)\end{array}$ \\
\hline The main wage earner is likely to die & & & $\begin{array}{l}0.05 * \\
(0.03)\end{array}$ & $\begin{array}{c}0.00 \\
(0.03)\end{array}$ \\
\hline \multicolumn{5}{|l|}{ Coping strategies: } \\
\hline Sell Assets & & & $\begin{array}{c}-0.02 \\
(0.03)\end{array}$ & $\begin{array}{c}0.00 \\
(0.10)\end{array}$ \\
\hline Take a formal loan & & & reference & reference \\
\hline Take an informal loan & & & $\begin{array}{c}-0.05 * * * \\
(0.02)\end{array}$ & $\begin{array}{c}-0.02 \\
(0.03)\end{array}$ \\
\hline Cash in insurance policies & & & $\begin{array}{c}0.07 \\
(0.05)\end{array}$ & $\begin{array}{c}-0.10^{* * *} \\
(0.04)\end{array}$ \\
\hline Apply for a govt. grant & & & $\begin{array}{c}0.01 \\
(0.03)\end{array}$ & $\begin{array}{c}0.01 \\
(0.05)\end{array}$ \\
\hline Withdraw Savings & & & $\begin{array}{l}-0.01 \\
(0.02)\end{array}$ & $\begin{array}{c}0.03 \\
(0.04)\end{array}$ \\
\hline Other Controls & & & & \\
\hline Control for gender (2 categories) & & & yes & yes \\
\hline Controls for age (13 categories) & & & yes & yes \\
\hline Controls for educational level (8 categories) & & & yes & yes \\
\hline Controls for national province ( 9 categories) & & & yes & yes \\
\hline Controls for geographical area (4 categories) & & & yes & yes \\
\hline Controls for ethnic group (4 categories) & & & yes & yes \\
\hline "Help available" & & & $\begin{array}{l}-0.00 \\
(0.01)\end{array}$ & $\begin{array}{c}0.03 \\
(0.02)\end{array}$ \\
\hline "Feel well" & & & $\begin{array}{l}-0.00 \\
(0.01)\end{array}$ & $\begin{array}{l}0.04 * \\
(0.02)\end{array}$ \\
\hline Head of household & & & $\begin{array}{c}0.03 * * \\
(0.02) \\
\end{array}$ & $\begin{array}{c}0.00 \\
(0.03) \\
\end{array}$ \\
\hline Number of observation & 2227 & 2227 & 2227 & 2224 \\
\hline Predicted Probability of y & 0.14 & 0.12 & 0.08 & 0.18 \\
\hline Pseudo-Rsquare & 0.16 & 0.23 & 0.35 & 0.16 \\
\hline Prob $>$ chi 2 & 0.00 & 0.00 & 0.00 & 0.00 \\
\hline
\end{tabular}

Notes: marginal effects of coefficient estimates from logistic regression, evaluated at means of all variables; for binary variables, $d y / d x$ is for discrete change of dummy variable from 0 to 1 . Robust standard errors are in parentheses.

Column (1)-(3): Dependent variable is 1 for holding a funeral policy/funeral scheme, 0 otherwise. Column (4):

Dependent variable is 1 for belonging to a burial society, 0 otherwise.

$* * * p<0.01, * * p<0.05$, * $p<0.1$.

Data source: FinScope South Africa 2004; see main text for details.

Remittances are a common phenomena in low- and middle-income countries. Money from family and friends increases income, enabling the recipient to buy more insurance products. The income variable captures this effect. At the same time, remittances can be 
regarded as self-insurance. As seen in Table 2, if the respondent receives remittances, he is 7 percent less likely to have a formal funeral cover. ${ }^{15}$ The effect proves robust in all three regressions. This is in line with Hypothesis 2. The self-insurance effect is evident, controlling for the household's income level. The interaction term capturing additional effects through the mutual influence of remittances and income level does not evolve as statistically significant in any model specification. This indicates that the self-insurance effect of remittances is independent of income. The question "Reasons for not having funeral/burial cover" provides support for the self-insurance effect of remittances. Among those who answer "Someone else will pay," a disproportionately high share of respondents (one-third) receives remittances. Moreover, remittances and the reason "Someone else will pay" for not having funeral cover are significantly (at 5\% level) and positively correlated.

We can probe the determinants of the funeral cover choice more deeply by looking at the banking variables. The Physical Access to Formal Financial Institutions Index has a positive and statistically highly significant impact on the dependent variable, increasing the probability of having formal funeral cover by 2 percentage points. Currently having or previously having had a bank account has an even greater impact on formal funeral cover. Another approximation for the respondent's familiarity with the banking system, the way the respondent receives his or her income ("Institutionalized money transfer"), also has a strong and significant positive impact on the choice of formal funeral cover, making it more likely that the respondent has a funeral policy or takes part in a funeral

\footnotetext{
${ }^{15}$ For simplicity, we use the gender-specific pronoun 'he' when we refer to the individual.
} 
scheme by about 5 percentage points. The results suggest that having a bank account, being physically close to financial institutions, or regularly using banking services increases the probability of having a formal funeral cover, thus confirming Hypothesis 3. This effect might reflect that familiarity with important aspects of an institutional system and the functioning of the banking systems augments the willingness to take formal insurance. Furthermore, regular interaction with a bank selling insurance raises the exposure to the bank's marketing activities.

Respondents who are inclined to deal with occurrences by taking an informal loan are systematically less likely to opt for formal funeral cover. The effect is rather sizeable at 5 percentage points. From the variables capturing risk perception in the model, we can deduce that respondents who note the death of the main wage earner as likely to happen in the near future have a 5 percentage point higher probability of owning a formal funeral insurance product. Notably, it makes no systematic difference for the purchase of formal funeral cover if some other household-specific or general risk may likely happen.

To test the hypothesis that the decision to join a burial society is driven by different factors than those driving the purchase of formal funeral cover, we run the same regression model on a dependent variable with the value 1 if the respondent belongs to a burial society and 0 otherwise.

It becomes very clear from column 4 in the regression table that income does not influence the burial society membership, and neither do remittances. Rather surprisingly, the fact of being banked exerts a positive impact on the probability of having informal 
funeral cover. Furthermore, people who indicate that their strategy of dealing with risk includes cashing in insurance policies after a negative income shock are less inclined to join a burial society.

The econometric results suggest that the decision to join burial societies is fundamentally different from the decision for formal funeral cover. Since the community of a burial society offers various non-monetary benefits, such as practical assistance with funeral arrangements and has bearings on the individual's network and community relations, membership in a burial society is a very different form of insuring than formal funeral cover.

\section{Discussion of results and conclusions}

We start our analysis with the question of whether an individual receiving remittances influences his use of funeral cover. From the empirical literature, we know that remittances increase after a disaster. This suggests that remittances act as self-insurance. At the same time, remittances increase income, which, ceteris paribus, should increase the use of insurance for low income individuals and decrease it for high income individuals. Our empirical analysis confirms these income effects. We also provide evidence that remittances decrease the likelihood that an individual has formal funeral cover after controlling for income. Thus, our results suggest that both risk management strategies are substitutes with respect to formal insurance but not informal group-based insurance arrangements.

We also examine the ways in which formal funeral cover is influenced by other risk management strategies. Here, we find some self-insurance effect. Individuals that 
consider taking an informal loan as an option to deal with occurrences are less likely to possess formal funeral cover. In contrast, access to banking services may increase the use of insurances. Indeed, we find that banked individuals are more likely to possess formal funeral cover, which is unexpectedly also true for membership in a burial society. Even though access to the formal financial system exists, the preference for traditional financial services leads to mixed usage of formal and informal financial services. The increased likelihood of being a burial society member and being banked constitutes an interesting case of coverage of different financial management needs through a mix of formal and informal financial services. This relationship should be explored further.

During an economic crisis, the independence of membership in a burial society from factors, such as remittances and income, can be an advantage for the migrant families compared to formal funeral cover. Considering the importance of funeral cover in preventing the detrimental effects of a death on the family, traditional coping mechanisms, such as burial societies, are fairly resistant to external influences. From the point of view of development, it is accordingly fundamental not to replace traditional group-based coping mechanisms with individual financial products because these products may only be short-term and leave the family without (funeral) cover in the long run. In countries like South Africa, with a high rate of premature deaths due to HIV/AIDS and other diseases, this is a relevant poverty risk for low-income families and should be considered when promoting pro-poor financial inclusion. 


\section{References}

Arun, T. \& Steiner, S. (2006) Micro-insurance in the context of social protection. In: Working Paper (No. 55). Manchester, UK: Brooks World Poverty Institute, pp. 1-13.

Cameron, B. (2003) All you need to know about funeral assurance [Internet]. Available from: http://www.persfin.co.za/index.php?fArticleId=222667\&fSectionId=733\&fSetId=300 [Accessed 22 March 2010].

Clark, G. R. G. \& Wallsten, S. J. (2003) Do remittances act like insurance? Evidence from a natural disaster in Jamaica, World Bank. Available at SSRN: http://ssrn.com/abstract=373480 or doi:10.2139/ssrn.373480 [Accessed 22 Mai 2010].

Churchill, C. (2006) What is insurance for the poor? In: Churchill, C. ed. Protecting the poor. A microinsurance compendium. Munich, Geneva: Munich Re Foundation, International Labor Office (ILO), pp. 12-24.

Cohen, M. \& Sebastad, J. (2006) The demand for microinsurance. In: Churchill, C. ed. Protecting the poor. A microinsurance compendium. Munich, Geneva: Munich Re Foundation, International Labor Office (ILO), pp. 25-44.

Collins, D. (2004) The financial diaries project - background and methodology [Internet]. Available from:: http://www.financialdiaries.com/methodology.htm (Accessed 29 March 2008).

Collins, D. (2005) Financial instruments of the poor: Initial findings from the financial diaries study. Development Southern Africa, 22 (5), pp. 717-728.

Collins, D. \& Morduch, J. (in press) Banking low-income populations: Perspectives from South Africa. In: Barr, M. \& Blank, R. eds. Access, assets, and poverty: The role of financial services among low- and moderate-income households.

Endo, I., Hirsch, S., Rogge, J. \& Borowik, K. (2010) The U.S. - Honduras remittance corridor. Working Paper, No 177, The World Bank.

Financial Diaries. (n.d.a) Focus note funerals and finance: Events in the lives of Financial Diaries households [Internet]. Available from:

http://www.financialdiaries.com/key_findings.htm (Accessed: 09 January 2009).

Financial Diaries. (n.d.b) Focus note financial decisions and funeral costs [Internet]. Available from: http://www.financialdiaries.com/key_findings.htm (Accessed: 09 January 2009). 
Gravelle, H. \& Rees, R. (2004) Microeconomics 3rd ed. Essex, UK, Pearson Education Limited.

Gubert, F. (2002) Do migrants insure those who stay behind? Evidence from the Kayes area (Western Mali), Oxford Development Studies, 30 (3), pp. 267-287.

Leite, P., McKinley, T. \& Guerreiro Osorio, R. (2006) The post-Apartheid evolution of earnings inequality in South Africa, 1995-2004 Working Paper of the International Poverty Centre. UNDP, 32 October.

Mohapatra, S., Joseph, G. \& Ratha, D. (2009) Remittances and natural disasters: Ex-post response and contribution to ex-ante preparedness. Working Paper, No. 4972, World Bank Policy Research.

Morduch, J. (1995) Income smoothing and consumption smoothing. Journal of Economic Perspectives, 9 (3), pp.103-114.

Napier, M.; Higgs, N.; Beghin, D.; Powell, R. (2007) Going out in style: The culture and finance of death in South Africa. FNS Research Surveys. Vorna Valley, South Africa: FinMark Trust.

Porteous, D. (2007) Financial service access and usage in Southern and East Africa: What do Finscope surveys tell us?

[Internet]. Vorna Valley, South Africa: FinMark Trust. Available from: http://www.finscope.co.za/index.asp (Accessed 11 January 2009).

Posel, D. (2003) Have migration patterns in post-Apartheid South Africa changed? Paper prepared for Conference on African Migration in Comparative Perspective, Johannesburg, South Africa, June, 4-7.

Rees, R. \& Wambach, A. (2008) Microeconomics of insurance, Hanover: Now Publishers.

Roth, J. (2000) Informal micro-finance schemes: The case of funeral insurance in South Africa. ILO Working Paper, No. 22. Geneva: ILO.

Rutherford, S. (2001) The poor and their money. New Delhi: Oxford University Press.

Ruthven, O. \& Kumar, S. (2002) Fine-grain finance: Financial choice and strategy among the poor in rural North India. Finance and Development Research Programme Working Paper Series, Vol. 57. Manchester: University of Manchester, Institute for Development Policy and Management.

Schlesinger, H. (2000) Insurance demand. In: Dionne, G. ed. Handbook of insurance. Boston: Kluwer Academic Publishers. 
Stone, R. (Emerging Market Economics Limited) (2005) Financial access indicators stocktake. A paper for the Department for International Development. London: Department for International Development (DFID).

UNDP. (2008) Human development report 2007/2008: Country Factsheet South Africa: The Human Development Index - going beyond income [Internet]. Available from: http://hdrstats.undp.org/en/countries/country_fact_sheets/cty_fs_ZAF.html (Accessed 31 August 2009).

World Bank. (2001) World development report 2000/2001: Attacking poverty: Opportunity, empowerment, and security. Oxford: Oxford University Press.

Yang, D. (2007) Coping with disaster: The impact of hurricanes on international financial flows, 1970-2002., Ann Arbor, MI: Mimeo, Department of Economics, University of Michigan.

Yang, D. \& Choi, H. (2007) Are remittances insurance? Evidence from rainfall shocks in the Philippines. World Bank Economic Review, 21(2), pp. 219-248.

Zeller, M. \& Sharma, M. (2000) Many borrow, more save, and all insure: Implications for food and micro-finance policy. Food Policy, 25 (2), pp. 143-167. 


\section{Appendix}

\section{A.1 Basic diagnostics}

The logistic regression analysis is based on various assumptions. In order for our analysis to be valid, our model has to satisfy the assumptions of logistic regression analysis. Therefore, we need to check that our model fits sufficiently well and check that the independent variables are not linear combinations of each other. We also need to assess whether influential observations might impact the estimates of the coefficients.

\section{A.1.1 Specification Errors}

After conducting our regressions (displayed in Table 2), we use a link test to ensure that our model has all the relevant predictors and if the linear combination of them is sufficient. The link test uses the linear predicted value (_hat) and linear predicted value squared (_hatsq) as the predictors to rebuild the model.

Table A1: Link test to detect a specification error (following regression (3), Table 2) dependent variable: holding a formal funeral cover

\begin{tabular}{lcccc} 
independent variable & Coefficient & Robust Std. Err. & $Z$ & $P>|z|$ \\
\hline _hat & 0.93 & 0.07 & 13.69 & 0.00 \\
_hatsq & -0.04 & 0.03 & -1.17 & 0.24 \\
-cons & 0.03 & 0.10 & 0.29 & 0.77 \\
\hline Number of observations & & & 2227 \\
Pseudo-Rsquare & & & 0.35 \\
Prob > chi2 & & & 0.00 \\
\hline \hline
\end{tabular}

Table A2: Link test to detect a specification error (following regression (4), Table 2) dependent variable: belonging to a burial society

\begin{tabular}{lcccc}
\multicolumn{1}{c}{ independent variable } & Coefficient & Robust Std. Err. & $Z$ & $P>|z|$ \\
\hline _hat & 1.00 & 0.13 & 7.49 & 0.00 \\
_hatsq & 0.00 & 0.05 & 0.04 & 0.97 \\
-cons & 0.00 & 0.10 & 0.01 & 0.99 \\
\hline Number of observations & & & 2224 \\
Pseudo-Rsquare & & & 0.16 \\
Prob > chi2 & & & 0.00 \\
\hline \hline
\end{tabular}


As can be seen in Tables A1 and A2 , the variable _hat is a statistically significant predictor. The fact that_hatsq is insignificant (with $p$-value $=0.24$ and 0.97 , respectively) confirms that the models are properly specified. These results indicate that we have not omitted relevant variables and that the logit function is the correct function to use.

\section{A.1.2 Multicollinearity}

Multicollinearity occurs when two or more independent variables in the model are determined by a linear combination of other independent variables in the model. Severe multicollinearity inflates the standard errors for the coefficients and it is impossible to obtain a reliable estimate of regression coefficients with all the independent variables in the model.

When we look at the correlation coefficients of the independent variables, the correlations between "Physical Access to formal fin. Institutions" and "Institutionalized money transfer" as well as between "Physical Access to formal fin. Institutions" and "Being banked" yield the highest coefficients with $\rho=0.42$ and $\rho=0.65$, respectively.

To measure the strength of the relationship among these independent variables more closely, we use the variance inflation factor (VIF). The VIF is close to 1 if all of the variables are completely uncorrelated with each other, and gets very large for high degrees of multicollinearity. We first run three ordinary least square regressions that have "Physical Access to formal fin. Institutions," "Institutionalized money transfer" and “Being banked,” respectively, as a function of all the other explanatory variables. From the VIFs for "Physical Access to formal fin. Institutions"(2.04), "Institutionalized money transfer” (1.28) and "Being banked” (1.81), we can conclude that there appears to be no multicollinearity problem (Kutner, Nachtsheim, \& Neter, 2004). ${ }^{16}$

\footnotetext{
${ }^{16}$ Kutner, Nachtsheim, Neter, Applied Linear Regression Models, 4th edition, McGraw-Hill Irwin (2004) propose 10 as a cut off value when multicollinearity is high.
} 


\section{A.1.3 Influential Observations}

Observations that have a significant impact on the model may skew the regression estimation. To identify potential outliers, we will make use of the Pregibon leverage, the standardized Pearson residuals, and the deviance residual. We look at these diagnostic measures by plotting them against the predicted probabilities of holding a formal funeral cover.

Figure A1: Plot of standardized Pearson residuals versus predicted probabilities

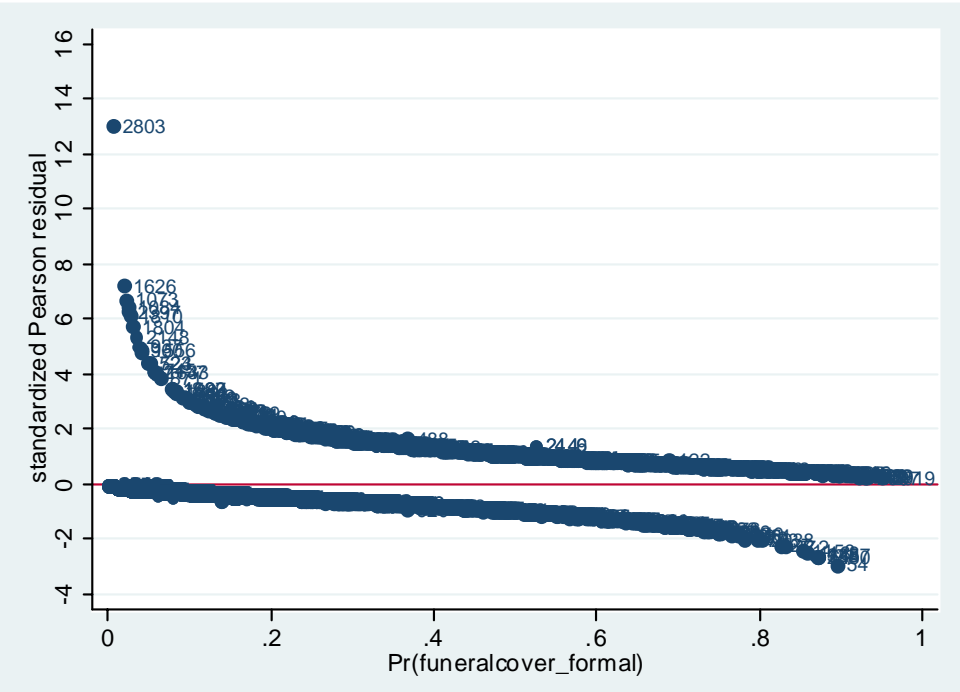

Figure A2: Plot of deviance residuals versus predicted probabilities

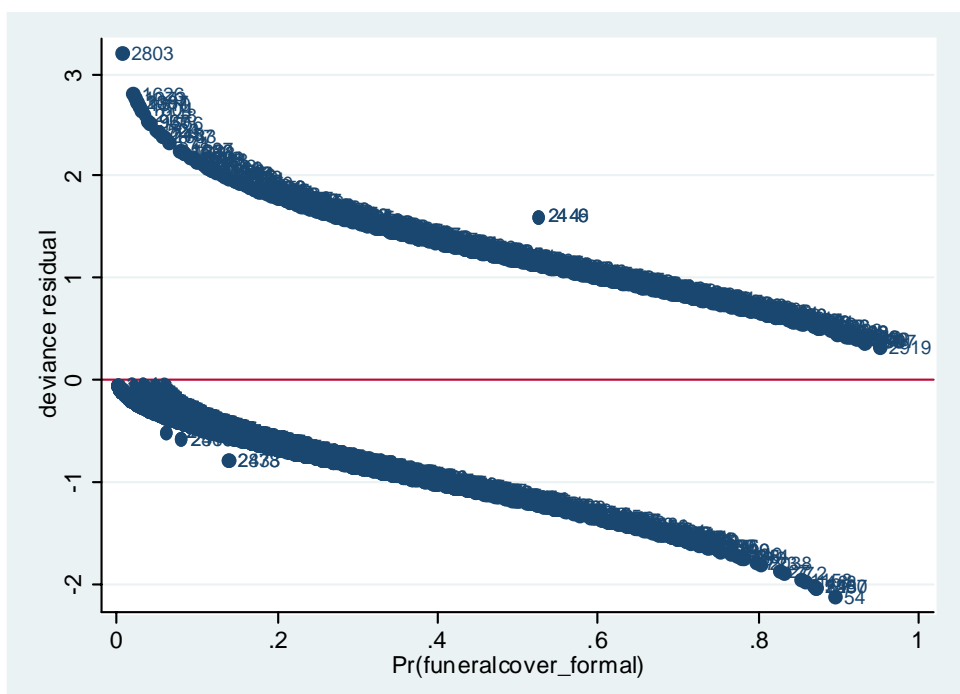


It becomes evident in Figure A1 and A2 that the observation with number 2803 is far away from the other observations. In Figure A2, observation 2440 appears to have a larger deviance residual than expected as well. The Pregibon leverage of observation 2803 amounts to 0.002 , while the leverage of case number 2440 totals 0.026 . Given an average leverage of 0.022 (standard deviation: 0.018), it seems that both observations are not characterized by an unusually high leverage. That is to say, both observations should not have a big influence on the logistic regression estimates. The comparison of the logistic regressions including the observations 2440 and 2803 and without them confirms that our regression coefficient estimates are not noticeably influenced by these cases (Table A3).

\section{Table A3: Formal Funeral Cover: Marginal effects from logistic regression}

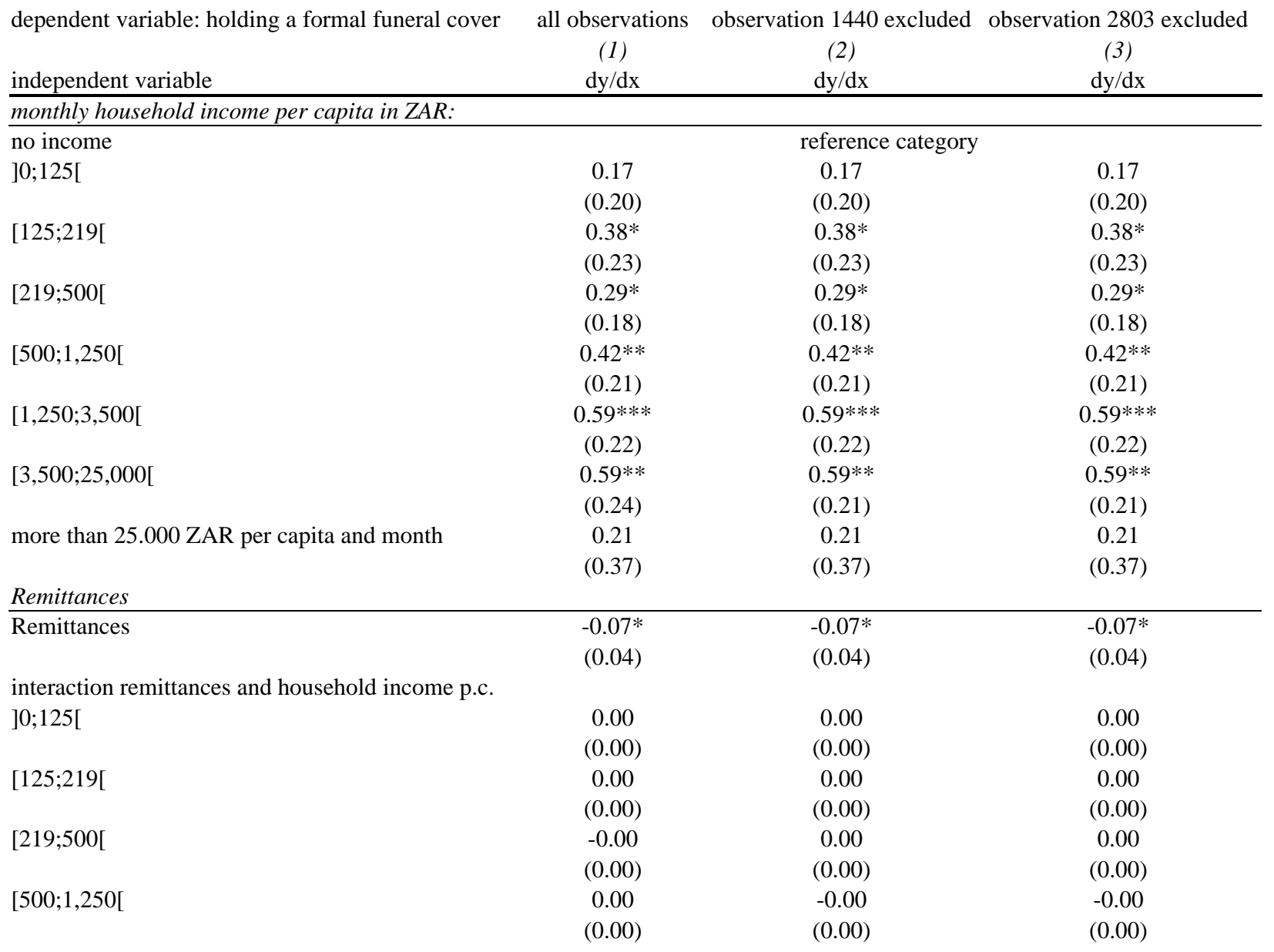




\begin{tabular}{|c|c|c|c|}
\hline$[3,500 ; 25,000[$ & $\begin{array}{c}0.00 \\
(0.00) \\
0.00 \\
(0.00)\end{array}$ & $\begin{array}{c}0.00 \\
(0.00) \\
0.00 \\
(0.00)\end{array}$ & $\begin{array}{c}0.00 \\
(0.00) \\
0.00 \\
(0.00)\end{array}$ \\
\hline \multicolumn{4}{|l|}{ Banking information: } \\
\hline being banked & $\begin{array}{c}0.04^{* *} \\
(0.02)\end{array}$ & $\begin{array}{c}0.04 * * \\
(0.02)\end{array}$ & $\begin{array}{c}0.04^{* *} \\
(0.02)\end{array}$ \\
\hline Institutionalized money transfer & $\begin{array}{c}0.05 * * * \\
(0.02)\end{array}$ & $\begin{array}{c}0.05 * * * \\
(0.02)\end{array}$ & $\begin{array}{c}0.05 * * * \\
(0.02)\end{array}$ \\
\hline Physical access to formal fin. Institutions & $\begin{array}{c}0.02 * * * \\
(0.00)\end{array}$ & $\begin{array}{c}0.02 * * * \\
(0.00)\end{array}$ & $\begin{array}{c}0.02 * * * \\
(0.00)\end{array}$ \\
\hline \multicolumn{4}{|l|}{ Risk perception: } \\
\hline a household-specific risk is likely to happen & $\begin{array}{c}0.02 \\
(0.02)\end{array}$ & $\begin{array}{c}0.02 \\
(0.02)\end{array}$ & $\begin{array}{c}0.02 \\
(0.02)\end{array}$ \\
\hline a general risk is likely to happen & $\begin{array}{c}0.02 \\
(0.02)\end{array}$ & $\begin{array}{c}0.02 \\
(0.02)\end{array}$ & $\begin{array}{c}0.02 \\
(0.02)\end{array}$ \\
\hline the main wage earner is likely to die & $\begin{array}{l}0.05^{*} \\
(0.03)\end{array}$ & $\begin{array}{l}0.05^{*} \\
(0.03)\end{array}$ & $\begin{array}{l}0.05^{*} \\
(0.03)\end{array}$ \\
\hline \multicolumn{4}{|l|}{ Coping strategies: } \\
\hline Sell Assets & $\begin{array}{l}-0.02 \\
(0.03)\end{array}$ & $\begin{array}{l}-0.02 \\
(0.03)\end{array}$ & $\begin{array}{l}-0.02 \\
(0.03)\end{array}$ \\
\hline Take a formal loan & & refer & \\
\hline Take an informal loan & $\begin{array}{c}-0.05^{* * *} \\
(0.02)\end{array}$ & $\begin{array}{c}-0.05^{* * *} \\
(0.02)\end{array}$ & $\begin{array}{c}-0.05^{* * *} \\
(0.02)\end{array}$ \\
\hline Cash in insurance policies & $\begin{array}{c}0.07 \\
(0.05)\end{array}$ & $\begin{array}{c}0.07 \\
(0.05)\end{array}$ & $\begin{array}{c}0.07 \\
(0.05)\end{array}$ \\
\hline Apply for a govt. grant & $\begin{array}{c}0.01 \\
(0.03)\end{array}$ & $\begin{array}{c}0.01 \\
(0.03)\end{array}$ & $\begin{array}{c}0.01 \\
(0.03)\end{array}$ \\
\hline Notes: marginal effects of coefficient estimates & $\begin{array}{l}-0.01 \\
(0.02)\end{array}$ & $\begin{array}{l}-0.01 \\
(0.02)\end{array}$ & $\begin{array}{l}-0.01 \\
(0.02)\end{array}$ \\
\hline \multicolumn{4}{|l|}{ Other Controls } \\
\hline Control for gender (2 categories) & yes & yes & yes \\
\hline Controls for age (13 categories) & yes & yes & yes \\
\hline Controls for educational level (8 categories) & yes & yes & yes \\
\hline Controls for national province (9 categories) & yes & yes & yes \\
\hline Controls for geographical area (4 categories) & yes & yes & yes \\
\hline Controls for ethnic group (4 categories) & yes & yes & yes \\
\hline "Help available" & $\begin{array}{l}-0.00 \\
(0.01)\end{array}$ & $\begin{array}{l}-0.00 \\
(0.01)\end{array}$ & $\begin{array}{l}-0.00 \\
(0.01)\end{array}$ \\
\hline "Feel well" & $\begin{array}{l}-0.00 \\
(0.01)\end{array}$ & $\begin{array}{l}-0.00 \\
(0.01)\end{array}$ & $\begin{array}{l}-0.00 \\
(0.01)\end{array}$ \\
\hline head of household & $\begin{array}{l}0.03 * * \\
(0.02) \\
\end{array}$ & $\begin{array}{l}0.03 * * \\
(0.02)\end{array}$ & $\begin{array}{l}0.03 * * \\
(0.02) \\
\end{array}$ \\
\hline Number of observation & 2227 & 2226 & 2226 \\
\hline Predicted Probability of y & 0.08 & 0.08 & 0.08 \\
\hline Pseudo-Rsquare & 0.35 & 0.35 & 0.35 \\
\hline Prob > chi 2 & 0.00 & 0.00 & 0.00 \\
\hline
\end{tabular}

Notes: marginal effects of coefficient estimates from logistic regression, evaluated at means of all variables; For binary variables, $\mathrm{dy} / \mathrm{dx}$ is for discrete change of dummy variable from 0 to 1 . Robust standard errors in parentheses. The first column is equal to Column (3) in Table 2. Column (1)-(3): Dependent variable is 1 for holding a funeral policy/funeral scheme, 0 otherwise. ${ }^{* *} \mathrm{p}<0.01$, ${ }^{* *} \mathrm{p}<0.05,{ }^{*} \mathrm{p}<0.1$.

Data source: FinScope South Africa 2004; see main text for details. 


\section{A.2 Regression coefficient estimates of the control variables}

For clarity, the coefficient estimates of the full set of control variables have not been shown in Table 2. Table A4 lists the regression results of the logistic regressions reported in Column (3) and (4) of Table 2 for the remaining control variables.

\section{Table A4: Marginal effects from logistic regression}

\begin{tabular}{|c|c|c|}
\hline $\begin{array}{l}\text { dependent variable: holding/ belonging to a... } \\
\text { independent variable }\end{array}$ & $\begin{array}{l}\text { formal funeral cover } \\
\text { (3) } \\
\mathrm{dy} / \mathrm{dx}\end{array}$ & $\begin{array}{c}\text { burial society } \\
\text { (4) } \\
\mathrm{dy} / \mathrm{dx} \\
\end{array}$ \\
\hline \multicolumn{3}{|l|}{ Control for gender: } \\
\hline male & \multicolumn{2}{|l|}{ reference } \\
\hline female & $\begin{array}{c}0.02 \\
(0.01)\end{array}$ & $\begin{array}{l}0.04 * \\
(0.02)\end{array}$ \\
\hline Age: & & \\
\hline 18-24 years & \multicolumn{2}{|l|}{ reference } \\
\hline $25-29$ years & $\begin{array}{l}0.13^{*} \\
(0.07)\end{array}$ & $\begin{array}{l}0.11^{*} \\
(0.07)\end{array}$ \\
\hline 30-34 years & $\begin{array}{c}0.19 * * \\
(0.08)\end{array}$ & $\begin{array}{c}0.20 * * * \\
(0.07)\end{array}$ \\
\hline 35-39 years & $\begin{array}{c}0.24 * * * \\
(0.09)\end{array}$ & $\begin{array}{c}0.24 * * * \\
(0.08)\end{array}$ \\
\hline 40-44 years & $\begin{array}{c}0.31 * * * \\
(0.11)\end{array}$ & $\begin{array}{c}0.29 * * * \\
(0.09)\end{array}$ \\
\hline 45-49 years & $\begin{array}{c}0.34 * * * \\
(0.12)\end{array}$ & $\begin{array}{c}0.25 * * * \\
(0.09)\end{array}$ \\
\hline $50-54$ years & $\begin{array}{c}0.37 * * * \\
(0.13)\end{array}$ & $\begin{array}{c}0.45^{* * *} \\
(0.09)\end{array}$ \\
\hline 55-59 years & $\begin{array}{c}0.25^{* *} \\
(0.12)\end{array}$ & $\begin{array}{c}0.52 * * * \\
(0.10)\end{array}$ \\
\hline 60-64 years & $\begin{array}{c}0.40 * * * \\
(0.13)\end{array}$ & $\begin{array}{c}0.52 * * * \\
(0.09)\end{array}$ \\
\hline 65 and older & $\begin{array}{c}0.28 * * * \\
(0.11)\end{array}$ & $\begin{array}{c}0.54^{* * *} \\
(0.09)\end{array}$ \\
\hline \multicolumn{3}{|l|}{ Educational level: } \\
\hline No formal education & \multicolumn{2}{|l|}{ reference } \\
\hline Some primary school & $\begin{array}{c}0.02 \\
(0.04)\end{array}$ & $\begin{array}{l}-0.02 \\
(0.04)\end{array}$ \\
\hline Primary school completed & $\begin{array}{c}0.04 \\
(0.05)\end{array}$ & $\begin{array}{c}0.01 \\
(0.05)\end{array}$ \\
\hline Some high school & $\begin{array}{c}0.02 \\
(0.04)\end{array}$ & $\begin{array}{c}0.03 \\
(0.04)\end{array}$ \\
\hline Matriculated & $\begin{array}{l}0.10^{*} \\
(0.06)\end{array}$ & $\begin{array}{c}0.03 \\
(0.05)\end{array}$ \\
\hline Some university & $\begin{array}{l}0.33 * \\
(0.17)\end{array}$ & $\begin{array}{c}0.02 \\
(0.11)\end{array}$ \\
\hline \multirow[t]{2}{*}{ University completed } & 0.13 & 0.03 \\
\hline & $39(0.10)$ & $(0.10)$ \\
\hline
\end{tabular}


Any other post-matric qualification

$\begin{array}{cc}0.15 & -0.09 * \\ (0.10) & (0.05)\end{array}$

Provinces:

Eastern Cape

Free State

(0.10)

Gauteng

$\begin{array}{cc} & \text { reference } \\ 0.01 & -0.11^{* * * *} \\ (0.03) & (0.03)\end{array}$

$\begin{array}{cc}(0.03) & (0.03) \\ -0.05 * * * & -0.00\end{array}$

Kwazulu Natal

(0.04)

$-0.05^{* * *}$

$-0.05$

(0.02)

(0.04)

Mpumalanga

$-0.04 * * *$

$-0.03$

(0.02)

(0.04)

Northern Province/Limpopo

$-0.06 * * *$

$0.12 * *$

(0.02) (0.06)

Northern Cape

$-0.02$

$-0.02$

$(0.02)$

(0.04)

North West

$0.05 * * *$

$0.13 * *$

(0.01)

(0.06)

Western Province

$-0.01$

0.03

(0.02)

(0.04)

Geographical Area:

Rural formal

reference

Tribal Land

$-0.03 \quad 0.10$ *

(0.03)

$(0.05)$

Urban formal

$-0.02$

0.03

(0.02)

(0.04)

Urban informal

$-0.02$

0.09

(0.03)

(0.06)

Ethnic group:

Black

White

reference

-0.01
$(0.02)$

Coloured

$0.11^{* * *}$

(0.04)

$-0.03$

(0.02)

$-0.19 * * *$

$(0.01)$

$-0.08 * * *$

$(0.02)$

Asian

$-0.15^{* * *}$

(0.02)

Notes: marginal effects of coefficient estimates from logistic regression, evaluated at means of all variables; For binary variables, dy/dx is for discrete change of dummy variable from 0 to 1 . Robust standard errors in parentheses. The first column refers to Column (3) in Table 2: Dependent variable is 1 for holding a funeral policy/funeral scheme, 0 otherwise. The second column refers to Column (4) in Table 2: Dependent variable is 1 for belonging to a burial society, 0 otherwise.

$* * * \mathrm{p}<0.01, * * \mathrm{p}<0.05, * \mathrm{p}<0.1$.

Data source: FinScope South Africa 2004; see main text for details. 


\section{CESifo Working Paper Series}

for full list see www.cesifo-group.org/wp

(address: Poschingerstr. 5, 81679 Munich, Germany, office@cesifo.de)

3053 Sören Blomquist and Laurent Simula, Marginal Deadweight Loss when the Income Tax is Nonlinear, May 2010

3054 Lukas Menkhoff, Carol L. Osler and Maik Schmeling, Limit-Order Submission Strategies under Asymmetric Information, May 2010

3055 M. Hashem Pesaran and Alexander Chudik, Econometric Analysis of High Dimensional VARs Featuring a Dominant Unit, May 2010

3056 Rabah Arezki and Frederick van der Ploeg, Do Natural Resources Depress Income Per Capita?, May 2010

3057 Joseph Plasmans and Ruslan Lukach, The Patterns of Inter-firm and Inter-industry Knowledge Flows in the Netherlands, May 2010

3058 Jenny E. Ligthart and Sebastian E. V. Werner, Has the Euro Affected the Choice of Invoicing Currency?, May 2010

3059 Håkan Selin, Marginal Tax Rates and Tax-Favoured Pension Savings of the SelfEmployed - Evidence from Sweden, May 2010

3060 Richard Cornes, Roger Hartley and Yuji Tamura, A New Approach to Solving Production-Appropriation Games with Many Heterogeneous Players, May 2010

3061 Ronald MacDonald and Flávio Vieira, A Panel Data Investigation of Real Exchange Rate Misalignment and Growth, May 2010

3062 Thomas Eichner and Rüdiger Pethig, Efficient Management of Insecure Fossil Fuel Imports through Taxing(!) Domestic Green Energy?, May 2010

3063 Vít Bubák, Evžen Kočenda and Filip Žikeš, Volatility Transmission in Emerging European Foreign Exchange Markets, May 2010

3064 Leonid V. Azarnert, Après nous le Déluge: Fertility and the Intensity of Struggle against Immigration, May 2010

3065 William E. Becker, William H. Greene and John J. Siegfried, Do Undergraduate Majors or Ph.D. Students Affect Faculty Size?, May 2010

3066 Johannes Becker, Strategic Trade Policy through the Tax System, May 2010

3067 Omer Biran and Françoise Forges, Core-stable Rings in Auctions with Independent Private Values, May 2010

3068 Torben M. Andersen, Why do Scandinavians Work?, May 2010 
3069 Andrey Launov and Klaus Wälde, Estimating Incentive and Welfare Effects of NonStationary Unemployment Benefits, May 2010

3070 Simon Gächter, Benedikt Herrmann and Christian Thöni, Culture and Cooperation, June 2010

3071 Mehmet Bac and Eren Inci, The Old-Boy Network and the Quality of Entrepreneurs, June 2010

3072 Krisztina Molnár and Sergio Santoro, Optimal Monetary Policy when Agents are Learning, June 2010

3073 Marcel Boyer and Donatella Porrini, Optimal Liability Sharing and Court Errors: An Exploratory Analysis, June 2010

3074 Guglielmo Maria Caporale, Roman Matousek and Chris Stewart, EU Banks Rating Assignments: Is there Heterogeneity between New and Old Member Countries? June 2010

3075 Assaf Razin and Efraim Sadka, Fiscal and Migration Competition, June 2010

3076 Shafik Hebous, Martin Ruf and Alfons Weichenrieder, The Effects of Taxation on the Location Decision of Multinational Firms: M\&A vs. Greenfield Investments, June 2010

3077 Alessandro Cigno, How to Deal with Covert Child Labour, and Give Children an Effective Education, in a Poor Developing Country: An Optimal Taxation Problem with Moral Hazard, June 2010

3078 Bruno S. Frey and Lasse Steiner, World Heritage List: Does it Make Sense?, June 2010

3079 Henning Bohn, The Economic Consequences of Rising U.S. Government Debt: Privileges at Risk, June 2010

3080 Rebeca Jiménez-Rodriguez, Amalia Morales-Zumaquero and Balázs Égert, The VARying Effect of Foreign Shocks in Central and Eastern Europe, June 2010

3081 Stephane Dees, M. Hashem Pesaran, L. Vanessa Smith and Ron P. Smith, Supply, Demand and Monetary Policy Shocks in a Multi-Country New Keynesian Model, June 2010

3082 Sara Amoroso, Peter Kort, Bertrand Melenberg, Joseph Plasmans and Mark Vancauteren, Firm Level Productivity under Imperfect Competition in Output and Labor Markets, June 2010

3083 Thomas Eichner and Rüdiger Pethig, International Carbon Emissions Trading and Strategic Incentives to Subsidize Green Energy, June 2010

3084 Henri Fraisse, Labour Disputes and the Game of Legal Representation, June 2010 
3085 Andrzej Baniak and Peter Grajzl, Interjurisdictional Linkages and the Scope for Interventionist Legal Harmonization, June 2010

3086 Oliver Falck and Ludger Woessmann, School Competition and Students' Entrepreneurial Intentions: International Evidence Using Historical Catholic Roots of Private Schooling, June 2010

3087 Bernd Hayo and Stefan Voigt, Determinants of Constitutional Change: Why do Countries Change their Form of Government?, June 2010

3088 Momi Dahan and Michel Strawczynski, Fiscal Rules and Composition Bias in OECD Countries, June 2010

3089 Marcel Fratzscher and Julien Reynaud, IMF Surveillance and Financial Markets - A Political Economy Analysis, June 2010

3090 Michel Beine, Elisabetta Lodigiani and Robert Vermeulen, Remittances and Financial Openness, June 2010

3091 Sebastian Kube and Christian Traxler, The Interaction of Legal and Social Norm Enforcement, June 2010

3092 Volker Grossmann, Thomas M. Steger and Timo Trimborn, Quantifying Optimal Growth Policy, June 2010

3093 Huw David Dixon, A Unified Framework for Using Micro-Data to Compare Dynamic Wage and Price Setting Models, June 2010

3094 Helmuth Cremer, Firouz Gahvari and Pierre Pestieau, Accidental Bequests: A Curse for the Rich and a Boon for the Poor, June 2010

3095 Frank Lichtenberg, The Contribution of Pharmaceutical Innovation to Longevity Growth in Germany and France, June 2010

3096 Simon P. Anderson, Øystein Foros and Hans Jarle Kind, Hotelling Competition with Multi-Purchasing: Time Magazine, Newsweek, or both?, June 2010

3097 Assar Lindbeck and Mats Persson, A Continuous Theory of Income Insurance, June 2010

3098 Thomas Moutos and Christos Tsitsikas, Whither Public Interest: The Case of Greece's Public Finance, June 2010

3099 Thomas Eichner and Thorsten Upmann, Labor Markets and Capital Tax Competition, June 2010

3100 Massimo Bordignon and Santino Piazza, Who do you Blame in Local Finance? An Analysis of Municipal Financing in Italy, June 2010 
3101 Kyriakos C. Neanidis, Financial Dollarization and European Union Membership, June 2010

3102 Maela Giofré, Investor Protection and Foreign Stakeholders, June 2010

3103 Andrea F. Presbitero and Alberto Zazzaro, Competition and Relationship Lending: Friends or Foes?, June 2010

3104 Dan Anderberg and Yu Zhu, The Effect of Education on Martial Status and Partner Characteristics: Evidence from the UK, June 2010

3105 Hendrik Jürges, Eberhard Kruk and Steffen Reinhold, The Effect of Compulsory Schooling on Health - Evidence from Biomarkers, June 2010

3106 Alessandro Gambini and Alberto Zazzaro, Long-Lasting Bank Relationships and Growth of Firms, June 2010

3107 Jenny E. Ligthart and Gerard C. van der Meijden, Coordinated Tax-Tariff Reforms, Informality, and Welfare Distribution, June 2010

3108 Vilen Lipatov and Alfons Weichenrieder, Optimal Income Taxation with Tax Competition, June 2010

3109 Malte Mosel, Competition, Imitation, and R\&D Productivity in a Growth Model with Sector-Specific Patent Protection, June 2010

3110 Balázs Égert, Catching-up and Inflation in Europe: Balassa-Samuelson, Engel's Law and other Culprits, June 2010

3111 Johannes Metzler and Ludger Woessmann, The Impact of Teacher Subject Knowledge on Student Achievement: Evidence from Within-Teacher Within-Student Variation, June 2010

3112 Leif Danziger, Uniform and Nonuniform Staggering of Wage Contracts, July 2010

3113 Wolfgang Buchholz and Wolfgang Peters, Equity as a Prerequisite for Stable Cooperation in a Public-Good Economy - The Core Revisited, July 2010

3114 Panu Poutvaara and Olli Ropponen, School Shootings and Student Performance, July 2010

3115 John Beirne, Guglielmo Maria Caporale and Nicola Spagnolo, Liquidity Risk, Credit Risk and the Overnight Interest Rate Spread: A Stochastic Volatility Modelling Approach, July 2010

3116 M. Hashem Pesaran, Predictability of Asset Returns and the Efficient Market Hypothesis, July 2010

3117 Dorothee Crayen, Christa Hainz and Christiane Ströh de Martínez, Remittances, Banking Status and the Usage of Insurance Schemes, July 2010 